\title{
EFEK RESTRIKSI KALORI DAN RESTRIKSI KALORI MIMETIK PADA TIKUS TUA
}

\author{
Nurliana $^{* 1,2)}$, Syahrijuita ${ }^{2)}$, Ika Yustisia ${ }^{1)}$, Agnes Kwenang ${ }^{1,2)}$, Marhaen Hardjo ${ }^{1,2)}$, \\ Gita Vita Soraya ${ }^{1)}$ \\ 1 Magister Ilmu Biomedik, Fakultas Kedokteran, Sekolah Pasca Sarjana Universitas Hasanuddin \\ 2 Departemen Biokimia, Fakultas Kedokteran, Universitas Bosowa \\ e-mail: nurliana36@gmail.com
}

\begin{abstract}
Abstrak
Secara global sekitar 2,3 miliar lansia mengalami overweight dan obesitas. Restriksi kalori adalah intervensi yang berpengaruh untuk memperpanjang hidup, namun sulit bagi setiap orang untuk menerapkan restriksi kalori seumur hidup. Oleh karena itu diperlukan intervensi lain yang memiliki manfaat sama dengan restriksi kalori. Penelitian ini bertujuan untuk mengetahui pengaruh restriksi kalori, dan restriksi kalori mimetik terhadap profil lipid tikus tua. Penelitian ini termasuk penelitian eksperimental menggunakan metode acak terkontrol dengan Pre and Post test with controlled group design. Menggunakan 18 ekor tikus dibagi menjadi 3 kelompok, A (kontrol), $B$ (restriksi kalori), dan C (restriksi kalori mimetik) dan tiap kelompok terdiri dari 6 ekor tikus. Uji One Way Anova digunakan untuk melihat perbedaan sebelum dan sesudah intervensi. Dari hasil uji perbandingan secara keseluruhan terdapat perbedaan kolesterol, trygliserida, LDL-Cholesterol, $H D L-C h o l e s t e r o l ~ s e r u m ~ t i k u s$ antara kelompok $A, B$, dan $C$ setelah 30 hari perlakuan dengan nilai $p<0.005$. Dari hasil penelitian dapat disimpulkan bahwa restriksi kalori dan restriksi kalori mimetik mempengaruhi profil lipid.
\end{abstract}

Kata kunci : restriksi kalori, restriksi kalori mimetik, profil lipid, penuaan

\begin{abstract}
Globally around 2.3 billion elderly are overweight and obese. Calorie restriction is a powerful intervention for prolonging life, but it is difficult for everyone to implement calorie restriction for life. Therefore, other interventions are needed that have the same benefits as calorie restriction. This study aims to determine the effect of calorie restriction, and mimetic calorie restriction on the lipid profile of elderly rats and includes an experimental study using a randomized controlled method with Pre and Post test with controlled group design. Using 18 rats were divided into 3 groups, A (control), B (calorie restriction), and $C$ (mimetic calorie restriction) and each group consisted of 6 rats. One Way Anova test was used to see the difference before and after the intervention. From the results of the overall comparison test, there were differences in cholesterol, triglycerides, $L D L$ Cholesterol, HDL-Cholesterol in rat serum between groups $A, B, C$, and D after 30 days of treatment with $p<0,005$. From the results of the study it can be concluded that calorie restriction and mimetic calorie restriction affect the lipid profile.
\end{abstract}

Keywords: calorie restriction, mimetic calorie restriction, intermittent fasting, lipid profile, aging

\section{PENDAHULUAN}

Penuaan adalah penurunan fungsional fisiologis yang bergantung pada waktu yang mempengaruhi sebagian besar organisme hidup, didukung oleh perubahan beberapa jalur molekuler, dan merupakan faktor risiko utama untuk berbagai penyakit tidak menular. Gaya hidup sangat berpengaruh pada laju penuaan. Misalnya, obesitas atau konsumsi kalori yang berlebihan dapat meningkatkan insiden patologi terkait usia seperti diabetes, stroke, kanker, dan penyakit kardiovaskuler. Upaya preventif yang dapat dilakukan adalah menjaga kadar kolesterol darah dalam batas normal. Diet memegang peranan penting dalam upaya pencegahan dan pengobatan penyakit (Rattan, 2014; Patterson et al., 2015).

Usia harapan hidup penduduk Indonesia 69,1 tahun pada periode 2005- 
2010 naik menjadi 70,1 tahun pada periode 2010-2015 dan menjadi 72,2 tahun pada periode 2030-2035. Usia harapan hidup orang Indonesia masih di bawah harapan hidup orang Singapura, Thailand, Brunei Darussalam, Malaysia dan Vietnam. Sementara itu, meskipun usia harapan hidup orang Indonesia semakin meningkat, tetapi potensi terkena penyakit tidak menular juga semakin meningkat (Pangkahila, 2013).

Peningkatan angka harapan hidup yang seiring dengan bertambahnya kejadian penyakit tidak akan memberikan manfaat yang menguntungkan (Badan Pusat Statistik, 2013). Oleh karena itu semakin bertambahnya populasi lansia dapat mengakibatkan masalah apabila tidak seiring dengan perilaku preventif terhadap penyakit. Diet restriksi kalori merupakan salah satu intervensi paling berpengaruh untuk memperpanjang hidup (Pangkahila, 2013; Liao, 2012). Tujuan kita bersama memiliki informasi cukup tentang intervensi pengobatan untuk mengembangkan prediksi strategi yang memungkinkan pendekatan pengobatan yang disesuaikan untuk mengoptimalkan penuaan yang sehat di Indonesia (Matos, 2020).

Geroscience telah berevolusi sebagai bidang yang berfokus pada pencegahan NCD (Non Communicable Disease) seperti obesitas, diabetes, dan penyakit Alzheimer yang berkaitan dengan usia, diharapkan biologi aging dapat diintervensi untuk menambah usia hidup sehat pada lansia.5 Menargetkan mekanisme yang mendasari efek perpanjangan usia terhadap restriksi kalori yaitu mengurangi asupan makanan tanpa kekurangan gizi, tetap menjadi satusatunya intervensi menjanjikan yang dapat memperpanjang penuaan yang sehat (Shintani et al., 2018)

Bahkan jika restriksi kalori memperpanjang umur manusia, sulit untuk menerapkan restriksi kalori jangka panjang pada manusia. Oleh karena itu, lebih disukai untuk mengembangkan metode atau senyawa yang mereproduksi efek restriksi kalori tanpa membatasi jumlah makanan. Konsep restriksi kalori mimetik diusulkan oleh Lane et al. Melalui sebuah studi tentang 2-deoksi-Dglukosa (2DG), yang menunjukkan bioaktivitas pada tikus. Restriksi kalori mimetik menunjukkan sistemik efek restriksi kalori dan secara luas tidak hanya mencakup senyawa tetapi juga metode seperti operasi bariatrik atau latihan (Java, 2018).

Tujuan dari penelitian ini Untuk mengetahui efek restriksi kalori dan puasa intermittent terhadap profil lipid dan berat badan pada tikus.

\section{METODE PENELITIAN}

Penelitian ini menggunakan desain penelitian eksperimental dengan menggunakan metode acak terkontrol dengan pola Pre and Post test with controlled group design. Penelitian ini dilaksanakan di Makassar pada bulan Januari-Maret 2020.

Penelitian ini menggunakan 18 ekor tikus putih jantan (Rattus norvegicus) galur Wistar yang dipilih dengan simple random sampling dan dibagi menjadi 3 kelompok. Masing-masing kelompok terdiri dari 6 tikus putih Wistar (Rattus Novergicus) jantan tua. Kelompok 1 adalah kelompok kontrol yang diberikan makanan standar dan minuman standar, kelompok 2 adalah kelompok yang diberikan perlakuan restriksi kalori 30\% makanan dan minum standar, kelompok 3 adalah kelompok yang diberi perlakuan makanan standar dan minuman standar juga diberi larutan metformin 9mg/200gr bobot tikus melalui mulut menggunakan alat sonde.

Dalam penelitian ini menggunakan rumus Resource Equation (Group comparasion, repeated measures-one between and one within factor repeated-measures ANOVA), yang digunakan untuk studi hewan yang membandingkan 3 kelompok atau lebih. Jumlah sampel tiap kelompok dengan menggunakan rumus sebagai berikut (Lluch, 2016).

Minimum $\mathrm{n}=10 / \mathrm{kr}+1$

Maximum $\mathrm{n}=20 / \mathrm{kr}+1$

Hewan coba tikus putih Wistar (Rattus norvegicus) jantan tua. Sampel diadaptasikan dengan tempat tinggal barunya, dengan pemberian makan berupa pakan van der Voer dan air sebagai air minum. Pakan dan air minum diberikan ad libitum. Perlakuan ini disamakan pada semua tikus. Adaptasi diberikan selama tujuh hari diharapkan hewan coba beradaptasi, tidak mengalami stress, dan sebisa mungkin memiliki situasi dan kondisi yang sama saat ingin memulai penelitian. 


\section{Pemeriksaan Profil Lipid}

Pemeriksaan profil lipid menggunakan alat spektrofotometer menggunakan kit reagen Glory diagnostics. Sampel dikondisikan dalam keadaan nyaman dan tidak stress, lalu bagian ekor tikus didesinfeksi menggunakan kapas alkohol $70 \%$. Selanjutnya darah diambil menggunakan dysposible syringe sebanyak 3 $\mathrm{ml}$, darah ditampung ke dalam tabung vacutainer tutup merah dan disentrifus dengan kecepatan $3.000 \mathrm{rpm}$ selama 15 menit, kemudian serumnya dipisahkan. Pengambilan sampel darah dilakukan pada hari ke 0 , hari ke 15 , dan 30 pasca perlakuan.

\section{Teknik Analisis Data}

Data Primer yang dikumpulkan dalam peneilitian ini meliputi data kadar Cholesterol total, kadar trygliserida, kadar LDL-Cholesterol, Kadar HDL-Cholesterol yang dilakukan dengan pengambilan darah serum dari tikus tua putih jantan.

Pada penelitian ini, uji normalitas data menggunakan Kolmogorov Smirnov, Uji One way Anova untuk membandingkan profil lipid tiap kelompok, dan Uji Lanjut Tukey HSD untuk untuk membandingkan profil lipid antar kelompok.
Penelitian ini telah mendapatkan persetujuan etik dari Komite Etik Penelitian Kesehatan Fakultas Kedokteran Universitas Hasanuddin (No.78/UN4.6.4.5.3.1/PP36/2021).

\section{HASIL DAN PEMBAHASAN}

Dari penelitian ini dapat dijabarkan hasil sebagai berikut:

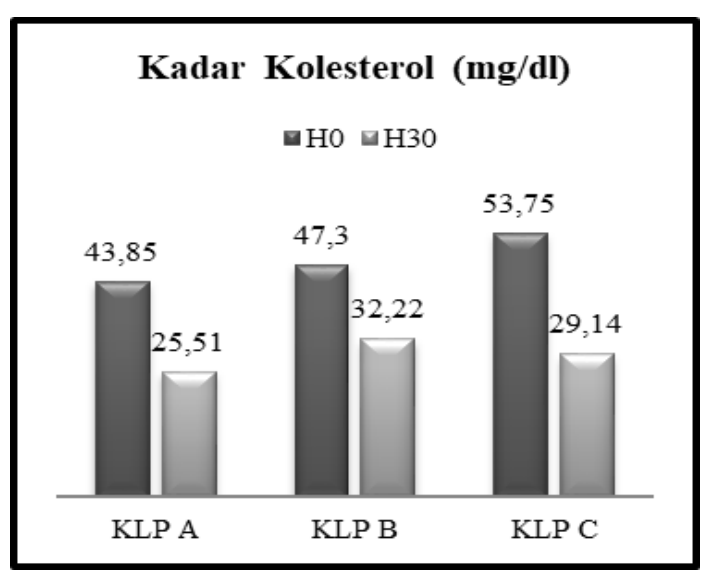

Gambar 1. Perbandingan hasil pemeriksaan kadar kolesterol serum tikus kelompok A (Kontrol), kelompok B (restriksi kalori 30\%), kelompok C (metformin), pada hari ke 0 , dan hari ke-30

Tabel 1. Hasil Uji Perbandingan Berat Badan Tikus Antar Waktu

\begin{tabular}{|c|c|c|c|c|c|c|c|c|}
\hline \multirow{2}{*}{ Kelompok } & \multirow{2}{*}{ Waktu } & \multirow{2}{*}{$\begin{array}{c}\text { Rata-rata } \\
\text { (gr) }\end{array}$} & \multicolumn{5}{|c|}{ Antar Waktu } & \multirow[b]{2}{*}{ Nilai $p$} \\
\hline & & & 0 & I & II & III & IV & \\
\hline \multirow[t]{5}{*}{$\mathrm{KO}$} & 0 & 245,66 & - & $p>0,05$ & $p>0,05$ & $p>0,05$ & $p>0,05$ & \multirow{5}{*}{$\begin{array}{l}p<0,05 \\
(0,028)\end{array}$} \\
\hline & I & 255,33 & & - & $p>0,05$ & $p<0,05$ & $p<0,05$ & \\
\hline & II & 265,83 & & & - & $p<0,05$ & $p<0,05$ & \\
\hline & III & 275,5 & & & & - & $p>0,05$ & \\
\hline & IV & 278,67 & & & & & - & \\
\hline \multirow[t]{5}{*}{ RK } & 0 & 278,5 & - & $p>0,05$ & $p>0,05$ & $p>0,05$ & $p>0,05$ & \multirow{5}{*}{$\begin{array}{c}p<0,05 \\
(0,025)\end{array}$} \\
\hline & I & 285,67 & & - & $p<0,05$ & $p>0,05$ & $p<0,05$ & \\
\hline & II & 276 & & & - & $p<0,05$ & $p<0,05$ & \\
\hline & III & 283 & & & & $\begin{array}{l}P \\
-\end{array}$ & $p<0,05$ & \\
\hline & IV & 269,5 & & & & & - & \\
\hline \multirow[t]{5}{*}{ RM } & 0 & 275 & - & $p>0,05$ & $p>0,05$ & $p>0,05$ & $p>0,05$ & \multirow{5}{*}{$\begin{array}{l}p>0,05 \\
(0,072)\end{array}$} \\
\hline & I & 280,17 & & - & $p>0,05$ & $p>0,05$ & $p>0,05$ & \\
\hline & II & 273 & & & - & $p>0,05$ & $p<0,05$ & \\
\hline & III & 279,83 & & & & $\begin{array}{c}-0,00 \\
-\end{array}$ & $p>0,05$ & \\
\hline & IV & 294,83 & & & & & - & \\
\hline \multirow[t]{5}{*}{ PI } & 0 & 306,16 & - & $p>0,05$ & $p>0,05$ & $p>0,05$ & $p>0,05$ & \multirow{5}{*}{$\begin{array}{l}p<0,05 \\
(0,018)\end{array}$} \\
\hline & I & 304,83 & & - & $p<0,05$ & $p<0,05$ & $p<0,05$ & \\
\hline & II & 255,5 & & & - & $p>0,05$ & $p>0,05$ & \\
\hline & III & 253,5 & & & & $P$ & $p>0,05$ & \\
\hline & IV & 255 & & & & & - & \\
\hline
\end{tabular}

Keterangan: Uji Signifikansi dengan repeated measures ANOVA $(p<0,05)$ 
Berdasarkan tabel 1 menunjukkan perbandingan berat badan berdasarkan kelompok dan waktu. Pada kelompok kontrol hasil rata-rata berat badan tikus terendah nampak pada pengukuran minggu nol sebesar 245,66, dan paling tinggi pada pengukuran minggu ke empat 278,67. Hal ini menunjukkan berat badan pada kelompok kontrol terus mengalami peningkatan selama perlakuan. Pada kelompok RK berat bada terendah pada minggu ke nol 278,5 dan tertinggi pada minggu ke satu sebesar 285,67. Pada kelompok RM berat badan terendah pada minggu ke nol 275 dan tertinggi pada minggu ke empat 294,83. Pada kelompok PI berat badan terendah pada minggu ke tiga 253,5 dan tertinggi pada minggu ke nol 306,16. Dan hasil uji statistik one-way ANOVA menunjukkan perbedaan signifikan pada $\mathrm{KO}$, RK, dan PI yang artinya terdapat pengaruh perlakuan terhadap tikus Wistar jantan pada kelompok tersebut.

Selama perlakuan tikus beraktivitas normal dan sehat. Dari penelitian ini dapat dilihat bahwa pada kelompok kontrol dan restriksi kalori mimetik setelah 30 hari perlakuan berat badan tikus mengalami peningkatan. Hal ini bisa dipengaruhi oleh kurangnya akitivitas tikus dalam kandang, dan semakin bertambahnya usia, metabolisme tubuh semakin menurun, sehingga berat badan akan meningkat, hal ini berkaitan dengan penggunaan hewan penelitian menggunakan tikus tua.

Namun pada kelompok restriksi kalori dan puasa intermittent berat badan tikus mengalami penurunan. Pada hasil sistematik review penelitian puasa intermittent menghasilkan penurunan berat badan mulai dari $0,8 \%$ sampai $13,0 \%$ dari berat badan awal dalam durasi penelitian 2-12 minggu, penurunan berat badan terjadi terlepas dari perubahan asupan kalori secara keseluruhan (Meng et al., 2020).

Penurunan berat badan melalui pembatasan kalori dan olahraga adalah rekomendasi lini pertama untuk obesitas dan gangguan terkait obesitas (yaitu, diabetes tipe-2, hiperlipidemia, hipertensi, sleep apnea dan sindrom polikistik ovarium polikistik) (Martin-
Montalvo et al., 2013). Meskipun beberapa terapi farmakologis telah terbukti bermanfaat untuk menurunkan berat badan, mempertahankan penurunan berat badan seringkali tidak mungkin dilakukan setelah penghentian agen farmakologis. Secara keseluruhan, pengurangan berat badan baik dengan modifikasi perilaku atau farmakoterapi berlangsung sekitar 1-2 tahun. Terapi restriksi kalori telah terbukti menurunkan berat badan, meningkatkan resistensi insulin, dan mengatur gangguan sistem kekebalan tubuh (Chen et al., 2015).

Penelitian pada manusia selama 2 tahun yang diberi restriksi kalori sebesar 15\% mengalami penurunan berat badan, pengurangan lemak tubuh, fluktuasi konsumsi energi, dan penurunan penanda stres oksidatif diamati, dan perubahan ini juga diamati pada model hewan percobaan (Shintani et al., 2018).

Sebagian besar penelitian hewan pengerat dan sejumlah kecil studi manusia telah menggunakan protokol intermittent energy restriction atau lebih dikenal dengan puasa intermittent, yang benar-benar membatasi asupan energi (pembatasan energy 100\%) setiap hari, dengan interval puasa berkisar antara 20 dan 36 jam. Selanjutnya protokol ini digunakan pada penelitian hewan pengerat telah diizinkan. Peneliti melaporkan penurunan berat badan melalui IER (pembatasan energi 70-100\%) berkisar antara sekitar 4 dan $10 \%$ selama periode diet 4-24 minggu. Terdapat perubahan peningkatan sensitivitas insulin dan perubahan profil lipid pada penelitian yang dilakukan 4 minggu hingga 1 tahun (Antoni et al., 2017).

Pada penelitian yang dilakukan oleh Varady dkk. untuk menilai efek puasa dan restriksi kalori terhadap proliferasi sel selama 4 minggu menggunakan tikus betina strain C57BL/6J menunjukkan berat badan kelompok puasa tidak berbeda dari kontrol, sedangkan kelompok restriksi kalori $25 \%$ mengalami penurunan dibandingkan kelompok lain setelah perawatan (Varady et al., 2011). Hal ini tidak sejalan dengan penelitian ini, dimana pada penelitian ini kelompok puasa lebih memiliki penurunan berat badan yang nyata dibandingkan dengan kelompok restriksi kalori. Hal ini 
bisa disebabkan oleh perbedaan hewan model yang digunakan.

Tabel 2. Hasil Pemeriksaan Kadar Kolesterol Kelompok A dan B

\begin{tabular}{ccccccc}
\hline \multirow{2}{*}{$\begin{array}{c}\text { Hari } \\
\text { Perlakuan }\end{array}$} & \multirow{2}{*}{ Kelompok } & Rata-rata & \multicolumn{3}{c}{ Post Hoc } & \multirow{2}{*}{ Nilai $\mathrm{p}$} \\
\cline { 4 - 6 } & H0 & 43,85 & $\mathrm{~A}$ & $\mathrm{~B}$ & $\mathrm{C}$ & \\
& $\mathrm{A}$ & 47,3 & $\mathrm{p}>0,05$ & $\mathrm{p}>0,05$ & $\mathrm{p}>0,05$ & $\mathrm{p}>0,05$ \\
& $\mathrm{~B}$ & 53,76 & $\mathrm{p}>0,05$ & $\mathrm{p}>0,05$ & $\mathrm{p}>0,05$ & 0,094 \\
H30 & $\mathrm{C}$ & 25,51 & - & $\mathrm{p}>0,05$ & $\mathrm{p}>0,05$ & $\mathrm{p}<0,05$ \\
& $\mathrm{~A}$ & 32,22 & $\mathrm{p}>0,05$ & - & $\mathrm{p}>0,05$ & 0,002 \\
& $\mathrm{~B}$ & 29,15 & $\mathrm{p}>0,05$ & $\mathrm{p}>0,05$ & - & \\
\hline
\end{tabular}

Keterangan: Uji Signifikansi dengan One-Way ANOVA $(\mathrm{p}<0.05)$

Setelah 30 hari perlakuan $(\mathrm{H} 30)$ diperoleh masing-masing nilai-rata kadar kolestrol pada kelompok A sebesar 25.51, kelompok B sebesar 32,22, kelompok C sebesar 29,15mg/dl. Rata-rata kadar kolesterol tertinggi terjadi pada kelompok B, sedangkan rata-rata kadar kolestrol terendah terjadi pada kelompok A. Hasil perbandingan kelompok $\mathrm{A}$ dan $\mathrm{B}, \mathrm{A}$ dan $\mathrm{C}$, B dan $\mathrm{C}$ tidak terdapat perbedaan yang signifikan dengan nilai $p>0,005$. Selain itu, pada perlakuan $\mathrm{H} 30$ diperoleh hasil uji perbandingan secara keseluruhan pada kelompok A, B, dan $\mathrm{C}$ menunjukkan nilai $\mathrm{p}$ value sebesar 0,002 yang lebih kecil daripada 0,05. Ini menunjukkan bahwa secara keseluruhan terdapat perbedaan kolestrol serum tikus antara kelompok A, B, dan $\mathrm{C}$ setelah 30 hari perlakuan.

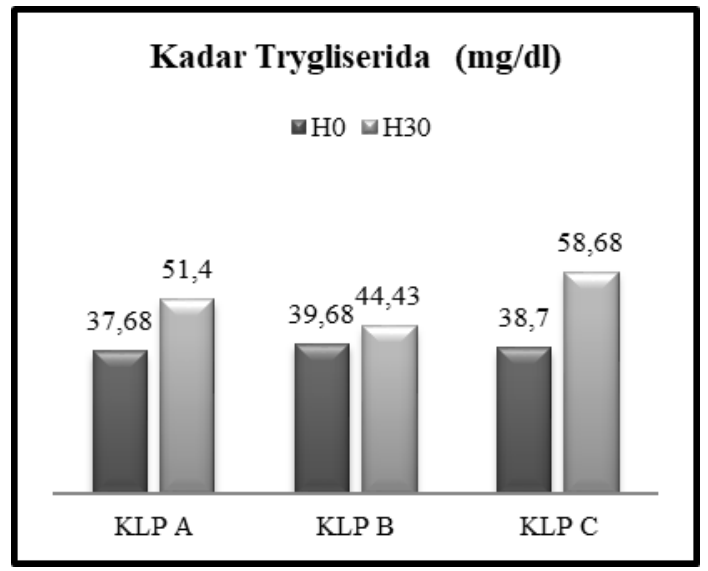

Gambar 2. Perbandingan hasil pemeriksaan kadar trygliserida serum tikus kelompok A (Kontrol), kelompok B (restriksi kalori 30\%), kelompok C (metformin), pada hari ke 0, dan hari ke-30.

Tabel 2. Hasil Pemeriksaan Kadar Trigliserida Kelompok A dan B

\begin{tabular}{ccccccc}
\hline \multirow{2}{*}{$\begin{array}{c}\text { Hari } \\
\text { Perlakuan }\end{array}$} & \multirow{2}{*}{ Kelompok } & \multirow{2}{*}{ Rata-rata } & \multicolumn{3}{c}{ Post Hoc } & \multirow{2}{*}{ Nilai $\mathrm{p}$} \\
\cline { 4 - 6 } & H0 & & $\mathrm{A}$ & $\mathrm{B}$ & $\mathrm{C}$ & \\
& $\mathrm{A}$ & 37.69 & - & $\mathrm{p}>0.05$ & $\mathrm{p}>0.05$ & $\mathrm{p}>0.05$ \\
& $\mathrm{~B}$ & 39.69 & $\mathrm{p}>0.05$ & - & $\mathrm{p}>0.05$ & 0.087 \\
H30 & $\mathrm{C}$ & 38.71 & $\mathrm{p}>0.05$ & $\mathrm{p}>0.05$ & - & \\
& $\mathrm{A}$ & 51.4 & - & $\mathrm{p}>0.05$ & $\mathrm{p}>0.05$ & $\mathrm{p}<0.05$ \\
& $\mathrm{~B}$ & 44.43 & $\mathrm{p}>0.05$ & - & $\mathrm{p}>0.05$ & 0.048 \\
\hline
\end{tabular}

Keterangan: Uji Signifikansi dengan One-Way ANOVA ( $<<0.05)$

Berdasarkan tabel 2 menunjukkan hasil uji perbadingan kadar trigliserida serum tikus antar kelompok perlakuan. Pada perlakuan H30 diperoleh masih-masing nilai-rata kadar trigliserida pada kelompok A sebesar 51,40, kelompok B sebesar 44.43, dan kelompok C sebesar 58,64. Rata-rata kadar trigliserida tertinggi terjadi pada kelompok $\mathrm{C}$, sedangkan rata-rata kadar trigliserida terendah terjadi pada kelompok
B. Hasil perbandingan kelompok A dan B, A dan $\mathrm{C}, \mathrm{B}$ dan $\mathrm{C}$ tidak terdapat perbedaan yang signifikan dengan nilai $\mathrm{p}>0,005$. Selain itu, pada hari perlakuan H30 diperoleh hasil uji perbandingan secara keseluruhan pada kelompok $\mathrm{A}, \mathrm{B}$, dan $\mathrm{C}$ menunjukkan nilai p-value sebesar 0.048 yang lebih kecil daripada 0.05. Ini menunjukkan bahwa secara keseluruhan terdapat perbedaan trigliserida serum tikus 
antara kelompok A, B, dan C perlakuan 30 hari.

Tabel 3. Hasil Pemeriksaan Kadar LDL Kolesterol Kelompok A dan B

\begin{tabular}{lcccc}
\hline \multirow{2}{*}{ Parameter } & KO & RK & RM & PI \\
\cline { 2 - 5 } & $\mathrm{H} 15$ & $\mathrm{H} 15$ & $\mathrm{H} 15$ & $\mathrm{H} 15$ \\
\hline Trigliserida & $66.13 \pm 19.25^{*}$ & $40.21 \pm 5.32^{*}$ & $69.34 \pm 17.19^{*}$ & $36.23 \pm 6.46^{*}$ \\
Kolesterol total & $35.01 \pm 4.26^{*}$ & $35.87 \pm 9.38^{*}$ & $33.30 \pm 4.57^{*}$ & $46.54 \pm 6.33^{*}$ \\
LDL-kolesterol & $121.16 \pm 35.40^{*}$ & $135.30 \pm 47.77^{*}$ & $138.43 \pm 39.26^{*}$ & $236.82 \pm 27.13^{*}$ \\
HDL kolesterol & $81.62 \pm 13.55$ & $85.65 \pm 14.59$ & $93.41 \pm 8.97$ & $73.27 \pm 12.75$ \\
\hline \multirow{2}{*}{ Parameter } & $\mathrm{KO}$ & $\mathrm{RK}$ & $\mathrm{RM}$ & $\mathrm{PI}$ \\
\cline { 2 - 5 } & $\mathrm{H} 30$ & $\mathrm{H} 30$ & $\mathrm{H} 30$ & $\mathrm{H} 30$ \\
\hline Trigliserida & $51.40 \pm 12.18$ & $44.43 \pm 11.45^{*}$ & $58.64 \pm 15.46^{*}$ & $66.64 \pm 13.18^{*}$ \\
Kolesterol total & $25.51 \pm 0.78$ & $32.22 \pm 8.26^{*}$ & $29.15 \pm 2.92^{*}$ & $42.60 \pm 10.15^{*}$ \\
LDL-kolesterol & $76.01 \pm 24.43$ & $187.87 \pm 51.11^{*}$ & $146.28 \pm 19.15^{*}$ & $216.24 \pm 45.52^{*}$ \\
HDL kolesterol & $111.38 \pm 4.82^{*}$ & $97.23 \pm 11.85^{*}$ & $89.52 \pm 7.81^{*}$ & $78.78 \pm 4.44^{*}$ \\
\hline
\end{tabular}

Keterangan: kelompok kontrol (KO), kelompok restriksi kalori (RK), kelompok restriksi kalori mimetik (RM), Kelompok puasa intermittent (PI) pada H0, H15, dan H30.

Pada penelitian ini ditemukan adanya perubahan profil lipid berupa penurunan kadar kolesterol total serum pada kelompok KO, kelompok RK kelompok RM, Kelompok PI setelah 15 hari dan setelah 30 hari perlakuan. Hal ini sesuai dengan penelitian sebelumnya dimana restriksi kalori dan puasa intermittent efektif dalam meningkatkan sirkulasi kolesterol total, LDL-kolesterol dan trigliserida. Namun puasa intermittent dan restriksi kalori tidak memiliki efek berarti pada kadar HDLkolesterol (Meng et al., 2020)

Pada kadar LDL-kolesterol, pada hari ke-15 terjadi penurunan kelompok KO, dan terjadi peningkatan kadar LDL-kolesterol pada kelompok RK, kelompok RM, Kelompok PI. Lalu pada hari ke-30 tetap terjadi penurunan pada kelompok $\mathrm{KO}$, dan terjadi peningkatan kadar LDL-kolesterol pada kelompok RK, RM, dan PI. Pada kadar HDL-kolesterol, pada hari ke-15 dan hari ke-30 terjadi peningkatan pada kelompok KO, RK, RM, dan PI.

Puasa intermittent dan diet kalori restriksi efektif dalam meningkatkan sirkulasi kolesterol total, LDL-kolesterol, dan kadar trigliserida. Namun tidak memiliki efek yang berarti pada kadar HDLkolesterol. Jadi dari hasil review meta analisis yang dilakukan puasa intermittent dan diet restriksi kalori efektif untuk meningkatkan konsentrasi kolesterol total, LDL-kolesterol, dan trigliserida yang bersirkulasi. Tetapi tidak memiliki efek yang berarti pada kadar HDL-kolesterol. Dan diet ini dapat meningkatkan profil lipid pada manusia (Meng et al., 2020). Dan ini sesuai dengan hasil penelitian yang kami dapatkan dimana pada kelompok restriksi kalori, restriksi kalori mimetik dan puasa intermittent dapat meningkatkan kadar kolesterol total, kadar trigliserida, kadar LDL-kolesterol, dan kadar HDL-kolesterol setelah 30 hari perlakuan.

Pada penelitian Alejandro dkk. mengenai metformin yang dapat meningkatkan kesehatan dan memperpanjang usia pada tikus jantan C57BL/6 yang berumur 84 minggu dan dilakukan diet selama 30 minggu menghasilkan penurunan berat badan pada tikus C57BL/6 pada perawatan minggu ke 72, dan pada perawatan selama 100 minggu menunjukkan peningkatan level metabolit terkait diabetes, dan penurunan nilai insulin, kolesterol total, dan LDLkolesterol. Jadi metformin dapat mencegah onset sistem metabolik dalam penggunaan jangka panjang (Martin-Montalvo et al., 2013).

Pada penelitian Jie Hua Cen dkk., yang dilakukan pada tikus selama 12 minggu, menghasilkan penurunan kadar trigliserida, peningkatan LDL-kolesterol, peningkatan HDL-kolesterol, dan peningkatan kadar kolesterol total pada restriksi karbohidrat sebanyak 60\%. Dan pada restriksi karbohidrat sebanyak $34 \%$ menghasilkan 
penurunan kadar trigliserida, peningkatan HDL-kolesterol, dan tidak ada perubahan pada kadar kolesterol total dan kadar LDLkolesterol (Chen et al., 2015).

Berdasarkan tabel 3 menunjukkan hasil uji perbadingan kadar HDL serum tikus antar kelompok perlakuan. Pada perlakuan H30 diperoleh masih-masing nilai-rata kadar HDL pada kelompok A sebesar 11.38, kelompok B sebesar 97.23, dan kelompok C sebesar 89,52. Rata-rata kadar HDL tertinggi terjadi pada kelompok A, sedangkan ratarata kadar HDL terendah terjadi pada kelompok A. Hasil perbandingan kelompok $\mathrm{A}$ dan $\mathrm{B}$, A dan $\mathrm{C}$, menunjukkan nilai $\mathrm{p}$ value yang lebih kecil daripada 0.05 $(\mathrm{P}<0,05)$ artinya terdapat berbeda signifikan. Sedangkan, hasil perbandingan kelompok B dan $\mathrm{C}$ menunjukkan nilai $\mathrm{p}$-value yang lebih besar daripada $0.05(\mathrm{P}>0.05)$ artinya tidak berbeda signifikan. Selain itu, pada hari perlakuan H30 diperoleh hasil uji perbandingan secara keseluruhan pada kelompok A, B, dan C menunjukkan nilai pvalue sebesar 0,000 yang lebih kecil daripada 0,05. Ini menunjukkan bahwa secara keseluruhan terdapat perbedaan HDL serum tikus antara kelompok A, B, dan C perlakuan 30 hari.

Pada penelitian yang dilakukan pada manusia dengan restriksi kalori sebanyak $25 \%$, selama dua tahun tidak memberikan perbedaan signifikan pada tekanan darah, glukosa darah puasa, insulin dan lipid (Ravussin et al., 2015). Restriksi kalori adalah intervensi paling andal untuk mencegah gangguan terkait usia dan memperpanjang umur. Pengurangan kalori sebesar 10-30\% dibandingkan dengan diet ad libitum yang diketahui memperpanjang umur panjang berbagai spesies dari ragi hingga hewan coba (tikus) (Willcox, 2016).

Restriksi kalori mimetik meniru efek biokimia dari kekurangan nutrisi, mengurangi asetilasi lisin protein seluler, sehingga memicu autofagi. Pengobatan dengan retriksi kalori mimetik hidroksisitrat, peng-hambat ATP sitrat lyase, menyebabkan penipisan sel $\mathrm{T}$ regulasi (yang mengurangi imunitas antikanker) dari autophagy-competent, tetapi tidak autophagy-deficient (Shafiq, 2017).

Metformin termasuk salah satu zat restriksi kalori mimetik, dapat meningkatkan usia hidup $\mathrm{C}$ elegans dan D. Melanogaster, yang dapat mengaktivasi AMPK dan juga merupakan obat golongan biguanide yang digunakan untuk penatalaksanaan Diabetes Mellitus. Dan pada dosis rendah juga terbutki dapat memberi efek yang sama dengan restriksi kalori melalui peningkatan sensitivitas insulin, mengurangi low density lipoprotein, dan mengurangi kadar kolsetrol dalam darah, dan meningkatkan proteksi terhadap antioxidant dan mengurangi inflamasi (Lluch, 2016). Pada penelitian ini juga menghasilkan penurunan kadar kolesterol sesuai dengan hasil penelitian dari Guillerno et al, namun pada penelitian ini terjadi peningkatan kadar LDL ini kemungkinan disebabkan oleh waktu perlakuan yang tergolong masih singkat, sehingga belum terjadi perubahan LDL yang bermakna.

Diet tinggi lemak menyebabkan hiperlipidemia, yang ditandai dengan peningkatan kolesterol total, trigliserida, LDL-C, dan penurunan HDL-C. Hiperlipidemia menyebabkan terjadinya aterosklerosis, salah satu faktor pemicunya penyakit kardiovaskular, seperti hipertensi; jantung koroner dan stroke (Java, 2018) Konsumsi lemak berlebih bisa meningkatkan kolesterol, LDL dan trigliserid serta menurunkan HDL. Salah satu cara untuk menurunkan kolesterol, LDL dan trigliserid serta menaikkan HDL dengan mengkonsumsi makanan yang mengandung antioksidan (Wurdianing, 2014).

Penelitian ini memiliki beberapa kelemahan. Pertama, waktu perlakuan yang masih singkat, sebaiknya dilakukan penelitian yang lebih lama, untuk lebih melihat terjadinya perubahan metabolisme pada tikus. Dan menarik pula untuk meneliti bahan restriksi kalori mimetik yang alami seperti dari ubi jalar, rumput laut, dan sebagainya.

\section{KESIMPULAN DAN SARAN}

Dari penelitian ini dapat disimpulkan bahwa pada kelompok restriksi kalori dan restriksi kalori mimetik terjadi penurunan kadar kolesterol dan peningkatan kadar trygliserida yang tidak berbeda signifikan bila dibandingkan tiap kelompok. Dan pada kadar Kadar LDL mengalami peningkatan pada kelompok restriksi kalori dan restriksi kalori mimetik, yang berbeda signifikan bila dibandingkan dengan kelompok kontrol. Pada Kadar HDL mengalami peningkatan pada kelompok restriksi kalori dan restriksi kalori mimetik, dan juga berbeda signifikan bila dibandingkan dengan kelompok kontrol. 
Namun secara keseluruhan pada kadar kolesterol, kadar trygliserida, kadar LDL, dan kadar HDL terdapat perbedaan signifikan antar kelompok setelah 30 hari perlakuan.

Sebaiknya pada kesempatan mendatang dilakukan penelitian mengenai restriksi kalori yang lebih mendalam ke arah perubahan genetik (FoxO1, mTOR, dan PGC1 $\alpha$ ) dan dalam periode waktu penelitian yang lebih panjang minimal agar terdapat perubahan yang signifikan pada metabolisme tikus.

\section{REFERENSI}

A., Shafiq, C. W. N. S. S. J. R. B. (2017) 'HHS Public Access', Physiology \& behavior, 176(3), pp. 139-148. doi: 10.1016/j.ccell.2016.05.016.Caloric.

Antoni, R. et al. (2017) 'Effects of intermittent fasting on glucose and lipid metabolism', Proceedings of the Nutrition Society, 76(3), pp. 361-368. doi: 10.1017/S0029665116002986.

Badan Pusat Statistik (2013) Proyeksi Penduduk Indonesia 2010-2035, Bps.

Chen, J. H. et al. (2015) 'A moderate lowcarbohydrate low-calorie diet improves lipid profile, insulin sensitivity and adiponectin expression in rats', Nutrients, 7(6), pp. 4724-4738. doi: 10.3390/nu7064724.

Java, C. (2018) 'Analysis of lipid profile and atherogenic index in hyperlipidemic rat (Rattus norvegicus Berkenhout, 1769) that given the methanolic extract of Parijoto (Medinilla speciosa) Analysis of Lipid Profile and Atherogenic Index in Hyperlipidemic', 090018(2017). doi: 10.1063/1.4985422.

Liao, C. Y. (2012) 'Restriction: from Life Extension to Life Shortening', NIH Public Access Author Manuscript Aging Cell. Author manuscript; available in PMC 2012 October 19., 9(1), pp. 92-95. doi: $10.1111 / \mathrm{j} .1474-$ 9726.2009.00533.x.Genetic.

López-Lluch, G. (2016) 'Calorie restriction as an intervention in ageing, Journal of Physiology, 594(8), pp. 2043-2060. doi: 10.1113/JP270543.

Martin-Montalvo, A. et al. (2013) 'Metformin improves healthspan and lifespan in mice', Nature Communications, 4. doi:
$10.1038 /$ ncomms 3192.

Meng, H. et al. (2020) 'Effects of intermittent fasting and energy-restricted diets on lipid profile: A systematic review and metaanalysis', Nutrition, 77, p. 110801. doi: 10.1016/j.nut.2020.110801.

Pangkahila, J. A. (2013) 'Pengaturan Pola Hidup dan Aktivitas Fisik Meningkatkan Umur Harapan Hidup', Sport and Fitness Journal, 1(1), pp. 14-27.

Patterson, R. E. et al. (2015) 'Intermittent Fasting and Human Metabolic Health', Journal of the Academy of Nutrition and Dietetics, 115(8), pp. 1203-1212. doi: 10.1016/j.jand.2015.02.018.

Perez-Matos, M. C. and Mair, W. B. (2020) 'Predicting longevity responses to dietary restriction: A stepping stone toward precision geroscience', PLoS genetics, 16(7), p. e1008833. doi: 10.1371/journal.pgen.1008833.

Rattan, S. I. S. (2014) 'Aging is not a disease: Implications for intervention', Aging and Disease, 5(3), pp. 196-202. doi: 10.14336/AD.2014.0500196.

Ravussin, E. et al. (2015) 'A 2-year randomized controlled trial of human caloric restriction: Feasibility and effects on predictors of health span and longevity', Journals of Gerontology - Series A Biological Sciences and Medical Sciences, 70(9), pp. 1097-1104. doi: 10.1093/gerona/glv057.

Shintani, H. et al. (2018) 'Calorie restriction mimetics: Upstream-type compounds for modulating glucose metabolism', Nutrients, 10(12), pp. 1-17. doi: 10.3390/nu10121821.

Varady, K. A. et al. (2011) 'Modified alternate- day fasting regimens reduce cell proliferation rates to a similar extent as daily calorie restriction in mice', The FASEB Journal, 22(6), pp. 2090-2096. doi: 10.1096/fj.07-098178.

Willcox BJ, W. D. (2016) 'Caloric Restriction, CR Mimetics, and Healthy Aging in Okinawa: Controversies and Clinical Implications', Curr Opin Clin Nutr Metab Care, 16(3), pp. 338-348. doi: 10.1097/MCO.000000000000019.Calori c.

Wurdianing, I. (2014) 'Efek ekstrak daun sirsak (Annona muricata Linn) terhadap profil lipid tikus putih jantan (Rattus Norvegicus)', 3(1), pp. 7-12. 